\title{
Lipophilic Composition from the Husks of Xanthoceras Sorbifolia and Their Antitumor and Antioxidant Activities
}

\author{
Chun yan Yang ${ }^{1,2 *}$, Yong $\mathrm{Lin}^{3 *}$, Wei Ha ${ }^{1}$, Jun li Yang ${ }^{1}$ and Yan ping Shi ${ }^{1}$ \\ ${ }^{1}$ CAS Key Laboratory of Chemistry of Northwestern Plant Resources and Key Laboratory for Natural Medicine of Gansu Province, China \\ ${ }^{2}$ School of Pharmacy, Institute of Materia Medica, North Sichuan Medical College, China \\ ${ }^{3}$ Department of Preventive Medicine, North Sichuan Medical College, China
}

Submission: December 16, 2016; Published: January 03, 2017

*Corresponding author: Chunyan Yang, School of Pharmacy, CAS Key Laboratory of Chemistry of Northwestern Plant Resources and Key Laboratory for Natural Medicine of Gansu Province, Lanzhou Institute of Chemical Physics, Chinese Academy of Sciences, Lanzhou 730000, China, Email: yangaccn@163.com

Yong Lin, Department of Preventive Medicine, North Sichuan Medical College, Nanchong 637007, China, Email: lin-yong@sina.com

\begin{abstract}
Xanthoceras sorbifolia Bunge. (XS) is a valuable oilseed crop in North China, and dimethyl phthalate (DMP) present in the husks of XS is also widely used in the insecticides, cosmetics, perfumes, and agricultural detergents. The aim of this study was to investigate the in vitro antitumor and antioxidant activities of the chloroform fraction (XSC) and DMP from the husks of XS. Gas chromatography-mass spectrometry (GC-MS) analysis led to the identification of DMP as the major constituent of XSC (84.18\%). Subsequently, XSC was subjected to the silica-gel chromatography to yield DMP. Antitumor assay showed that both XSC and DMP exhibited cytotoxic activity against four cancer cell lines (A549, HepG2, MGC-803, and MFC). Furthermore, both XSC and DMP exhibited antioxidant activity against ABTS 2, 2'-azino-bis (3-ethylbenzothiazoline-6-sulfonic acid) diammonium salt assay. In addition, calculations along with literature investigations showed that scavenging free radicals might be one of the mechanisms of the tumor-inhibiting activities of XSC and DMP. The obtained results, therefore, suggested that XSC and DMP might be used as a remedy for cancer disorders.
\end{abstract}

Keywords: Xanthoceras sorbifolia; Gas chromatography-mass spectrometry; Lipophilic composition; Antitumor activity; Antioxidant activity; MTT: 3-(4, 5-dimethylthiazol-2-yl)-2, 5-diphenyl tetrazolium bromide; A549: Human lung adenocarcinma cell line; HepG2: Human liver cancer cell line; MGC- 803 Human gastric carcinoma cell line; ABTS: 2, 2'-azino-bis (3-ethylbenzothiazoline-6-sulfonic acid) diammonium salt

Abbreviations: XS: Xanthoceras sorbifolia Bunge.; XSC: The chloroform fraction from the husks of XS; DMP: Dimethyl phthalate; GC-MS: Gas chromatography-mass spectrometry; CC: Column chromatography; $\mathrm{CDCl}_{3}$ : Deuterated chloroform; TMS: Tetramethylsilane; NMR: Nuclear magnetic resonance; PBS: Phosphate buffered saline; DMEM: Dulbecco's modified Eagle's medium; FBS: Fetal bovine serum; PTX: Paclitaxel; MFC: Murine foregastric carcinoma cell line

\section{Introduction}

Xanthoceras sorbifolia Bunge. belongs to the family Sapindaceae, a deciduous shrub and a valuable oilseed crop with a lifetime of more than 200 years [1]. X. sorbifolia is indigenous to China, and is extensively distributed in North China with a cultivation area of about $3 \times 104$ ha, from latitude $32^{\circ} 30^{\circ}$ to $45^{\circ}$, longitude $100^{\circ}$ to $127^{\circ}$ [2]. $X$. sorbifolia can grow well in barren, salty and alkali soil, and is even hardy down to -40 ${ }^{\circ} \mathrm{C}$. It is also cultivated in public gardens for ornamentation [3]. Traditionally, $X$. sorbifolia is used as a Chinese medicine for curing arterial sclerosis, rheumatism, hyperpiesia, chronic hepatitis, and enuresis of children [4]. It has also been included in China Pharmacopoeia (1977 edition) [5]. A variety of bioactive constituents have been isolated from this plant, such as triterpenoid saponins [5,6], polyphenols [7], and sterols [6]. The husks of XS are the by-products of XS, and presently the literature only reports that it can be used as activated carbons, furfural (containing 12\%), xylitol, alcohol, and other chemical raw materials [5]. However, the lipophilic composition and the antioxidant and antitumor activities of the lipophilic composition from the husks of $X$. sorbifolia have never been reported.

Cancer, as the second leading cause of death just after cardiovascular disease, has endangered mankind for centuries. Although the effectiveness of drug treatment for cancer has improved, producing serious side effects and increasing 
tolerance by cancers over time are still terrible problems [8]. Therefore, the discovery of novel, more specific anticancer components, with better treatment effects, is vital for anticancer therapy [9]. On the other hand, oxidative stress processes occur due to the existence of an imbalance between reactive oxygen species (ROS) and antioxidant enzymes, in favor of the excessive generation of ROS or due to their reduced rate of removal. Among the antioxidative enzymes, TRX (thioredoxin-1) can interact with several transcription factors (including $\mathrm{p}$ 53 , nuclear factor- $\kappa B$ and activating protein-1 via Ref-1), the decrease of which can increase the intracellular ROS [10]. These processes lead to biomolecule oxidation that in humans causes a series of cell disorders such as protein and enzymatic damage, lipophilic peroxidation, along with DNA alterations, which can be associated with many harmful processes such as cancer [11]. Antioxidants are known to protect against oxidative stress, which has been involved in the development of several chronic illnesses, including cancer [12]. Therefore, it is necessary to exploit and utilize natural antioxidants and antitumor agents so that they can help human protect against oxidative stress and also can be used in cancer treatment.

In the present study, the most significant lipophilic compound DMP from XSC in the husks of X. sorbifolia was firstly analyzed using GC-MS and subsequently isolated by silica-gel chromatography column. Furthermore, the antioxidant activities of DMP and XSC were examined by ABTS method. Finally, their antitumor activities of XSC and DMP were evaluated by assessing their in vitro cytotoxic activity against four cancer cell lines (A549, HepG2, MGC-803, and MFC) using the MTT method. Furthermore, the relationships between antioxidant and antitumor activities of XSC and DMP at different concentrations were tentatively discussed.

\section{Materials and Methods \\ General}

Column chromatography (CC) was conducted using silica gel $\left(\mathrm{SiO}_{2}, 200-300\right.$ mesh; Qingdao Haiyang Chemical Co., Ltd., Qingdao, China). Silica $\mathrm{GF}_{254}$ (10-40 mm) for TLC were supplied by the Qingdao Marine Chemical Factory, Qingdao, China. All TLC spots were visualised under UV light (254 $\mathrm{nm}$ ) and developed with iodine vapor. NMR spectra were recorded on Varian INOVA-400 spectrometers. Chemical shifts were given on a $\delta(\mathrm{ppm})$ scale using TMS as internal standard. 2,2'-zino-bis (3-ethylbenzothiazoline-6-sulfonic acid) diammonium salt (ABTS) and 3-(4, 5-dimethylthiazol-2-yl)-2, 5-diphenyltetrazolium bromide (MTT) were obtained from Aladdin Industrial Co., Shanghai, China.

\section{Plant material and reagents}

X. sorbifolia husks (Sapindaceae) were collected from Gansu Province, China, in 2013, and authenticated by Associate Prof. Huan-yang Qi (Lanzhou Institute of Chemical Physics, Chinese Academy of Sciences). A voucher specimen (NO. 20131106XSB) was deposited in the Key Laboratory of Chemistry of Northwestern Plant Resources and Key Laboratory for Natural Medicine of Gansu Province, Chinese Academy of Sciences. All other chemicals were of analytical grade.

\section{Extraction and isolation}

The air-dried and powdered husks of $X$. sorbifolia (100.93 g) were refluxed four times with methanol $\left(\mathrm{V}_{\text {material }}: \mathrm{V}_{\text {methanol }}=1: 10\right)$ under reflux for $2 \mathrm{~h}$, and then filtered. The clarified solvent was concentrated under reduced pressure to afford the raw extract (11.18 g), which was suspended in distilled water $(200 \mathrm{~mL})$ and partitioned successively against chloroform $(100 \mathrm{~mL} \times 4)$, and n-butanol $(100 \mathrm{~mL} \times 4)$ to yield the chloroform soluble fraction (XSC: $1.73 \mathrm{~g}$ ), the n-butanol soluble fraction (XSB: $2.47 \mathrm{~g}$ ), and the aqueous fraction (XSW: $6.75 \mathrm{~g}$ ). The XSC extracts $(3.20 \mathrm{mg}$ ) were dissolved in chloroform $(3.20 \mathrm{~mL})$, and then $2 \mu \mathrm{L}$ of the solution was subjected to GC-MS analysis. At the same time, the XSC extracts $(1.50 \mathrm{~g})$ were subjected to further purification over a silica-gel column. An elution of petroleum-ethyl acetate (10:1) was done to yield DMP (149.62 mg).

\section{GC-MS analysis}

We used an Agilent Technologies Series 6890 chromatograph with an Agilent DB-5 MS (5\% phenyl) capillary chromatography column (30 $\mathrm{m} \times 0.25 \mathrm{~mm})$ and a Series 5973 mass spectrometer. Temperatures of the injector and detector were $270{ }^{\circ} \mathrm{C}$. A temperature gradient system was used for the oven, starting at $100{ }^{\circ} \mathrm{C}$ and increasing up to $240{ }^{\circ} \mathrm{C}$ at a rate of $10{ }^{\circ} \mathrm{C} / \mathrm{min}$, and increasing up to $280^{\circ} \mathrm{C}$ at a rate of $5^{\circ} \mathrm{C} / \mathrm{min}$ and keeping it for $5 \mathrm{~min}$, and increasing up to $290{ }^{\circ} \mathrm{C}$ at a rate of $10{ }^{\circ} \mathrm{C} / \mathrm{min}$ and keeping it for $5 \mathrm{~min}$. The carrier gas was He at a flow rate $1.0 \mathrm{~mL} /$ min. Compounds were identified using NIST 2.0 and Wiley 138 mass spectra libraries.

\section{Biological study}

Cell lines and culture: Human lung adenocarcinma cell line (A549), Human liver cancer cell line (HepG2), Human gastric carcinoma cell line (MGC-803), and murine foregastric carcinoma cell line (MFC) were obtained from Shanghai Cell Bank of Chinese Academy of Sciences (Shanghai, China) and maintained with DMEM medium (Hyclone, USA) containing $10 \%$ fetal bovine serum (Hyclone, USA) and $100 \mathrm{ng} / \mathrm{mL}$, each, of penicillin and streptomycin at $37^{\circ} \mathrm{C}$ in a humidified atmosphere with $5 \% \mathrm{CO}_{2}$. The cytotoxicity study was performed when the cells reached $70-80 \%$ confluence.

In vitro antitumor assay: DMP and XSC were evaluated for their antitumor activity against cancer cell lines such as A549, HepG2, MGC-803, and MFC. The antitumor assay was performed according to the 3-(4, 5-dimethylthiazol-2-yl)-2, 5-diphenyl tetrazolium bromide (MTT) method [13] with some modifications. In brief, HepG2, A549, MGC-803, and MFC cells were seeded into 96 well plates $\left(5 \times 10^{3}\right.$ cells/well $)$, in a volume of $180 \mu \mathrm{L}$ of supplemented culture media, for $20-24 \mathrm{~h}$ to form the confluent monolayer under the above conditions, followed 


\section{Journal of Complementary Medicine \& Alternative Healthcare}

by treatment with concentrations $(500.00,250.00,125.00$, $62.50,31.25,15.63 \mu \mathrm{g} / \mathrm{mL}$, final concentrations) of the tested components, and further incubated for $24 \mathrm{~h}$ under the same conditions. Then $20 \mu \mathrm{L}$ of MTT stock solution ( $5 \mathrm{mg} / \mathrm{mL}$ in PBS) was added to each well. After incubation for $4 \mathrm{~h}$, the supernatants were removed, and $150 \mu \mathrm{L}$ of DMSO was added to each well. The absorbance was determined on a Multiskan MK 3 Automated Microplate Reader at $490 \mathrm{~nm}$ after 10 minutes. The percentage inhibitions were calculated by the equation in Section 2.6.

Antioxidant assay: The ABTS free radical scavenging activity of DMP and XSC was determined by the method described by Yang et al. [14] with some modifications. Briefly, $10 \mathrm{~mL} 2 \mathrm{mmol}$. $\mathrm{L}^{-1}$ ABTS solution was mixed well with $100 \mu \mathrm{L} 70 \mathrm{mmol} \mathrm{L}^{-1}$ potassium per sulfate water solution (ultimate concentration) and left standing overnight in the dark at room temperature to generate ABTS ${ }^{+}$. L-ascorbic acid was used as positive control. Assays were performed in 96-well plates. The ABTS radical cation solution was diluted with ethanol to an absorbance of $0.70 \pm 0.02$ at $734 \mathrm{~nm}$ and equilibrated at room temperature. After the addition of $20 \mu \mathrm{L}$ (final concentrations of 500.00, 250.00, 125.00, $62.50,31.25,15.63 \mu \mathrm{g} / \mathrm{mL}$ ) of DMP and XSC to $180 \mu \mathrm{L}$ of diluted $\mathrm{ABTS}^{+}+$solution, the absorbance reading was taken 10 min later after initial mixing. The percentage inhibitions were calculated by the equation in Section 2.6.

\section{Calculation of the inhibition percentage}

The percentage inhibitions were calculated by the following equation:

$$
A A(\%)=\left[1-\dot{A} i / A{ }^{\prime}\right] \times 100 \%
$$

Where AA was the inhibition percentage, Ao was the absorbance of the blank control; Ai was the absorbance of the test sample.

\section{Statistical analysis}

All experiments were carried out in three times. The sample concentrations providing $50 \%$ scavenging capacity $\left(\mathrm{SC}_{50}\right)$ were gained by fitting dose-response data to a four-parametric logistic nonlinear regression model using Graph Pad Prism 5.0 software (Graph Pad, La Jolla, CA). Correlation coefficient $\left(\mathrm{R}^{2}\right)$ analysis was performed on a personal computer using the statistical software package SPSS version 18.0 (SPSS inc).

\section{Results and Discussion}

\section{Gas chromatography-mass spectroscopic study of XSC in the husks of $X$. sorbifolia}

Preliminary GC-MS analysis, based on retention time and molecular mass, was performed to determine the nature of the lipophilic composition present in XSC. The GC-MS data and the library search successfully enabled the identification of nineteen compounds based on their retention time (RT) and concentration (peak area \%) (Table $1 \&$ supplementary Figure S1). The results revealed that DMP (84.18\%) was found to be the dominant component in XSC. As in Section 2.3, 1.50 g XSC gave the isolation of $149.62 \mathrm{mg}$ DMP (9.97\%), indicating that there were other lipophilic compositions in XSC that could not be determined using GC-MS. However, to the best of our knowledge, this was the first study of the lipophilic compositions from the husks of XS using GC-MS.

Table 1: Lipophilic composition of XSC analyzed by Gas chromatography-mass spectroscopy (GC-MS).

\begin{tabular}{|c|c|c|c|}
\hline Peak & RT, Min & Compound & Area $\%$ \\
\hline 1 & 7.48 & Dimethyl phthalate & 84.18 \\
\hline 2 & 11.22 & Pentadecanenitrile & 0.43 \\
\hline 3 & 12.46 & $\begin{array}{c}\text { Hexadecanoic acid, methyl } \\
\text { ester }\end{array}$ & 0.2 \\
\hline 4 & 12.95 & n-Hexadecanoic acid & 0.23 \\
\hline 5 & 13.1 & $\begin{array}{c}\text { Hexadecanoic acid, ethyl } \\
\text { ester }\end{array}$ & 0.3 \\
\hline 6 & 13.27 & Heptadecanenitrile & 0.47 \\
\hline 7 & 14.1 & Heneicosane & 0.13 \\
\hline 8 & 14.37 & $\begin{array}{l}\text { Heptadecanoic acid, } \\
\text { 15-methyl-, methyl ester }\end{array}$ & 0.14 \\
\hline 9 & 14.67 & Unknown & 3.35 \\
\hline 10 & 15.05 & Pentadecane & 0.52 \\
\hline 11 & 16.05 & Tricosane & 0.76 \\
\hline 12 & 16.9 & 9-Octadecenamide, (Z) & 0.64 \\
\hline 13 & 17.1 & Tetracosane & 0.94 \\
\hline 14 & 18.2 & Pentacosane & 0.98 \\
\hline 15 & 19.34 & Hexacosane & 0.71 \\
\hline 16 & 20.5 & Heneicosane & 0.74 \\
\hline 17 & 21.69 & Octacosane & 0.31 \\
\hline 18 & 26.13 & Eicosane & 0.28 \\
\hline 19 & 30.64 & $\begin{array}{l}\text { Stigmasta-7, 16-dien-3-ol, } \\
\text { (3. beta., 5. alpha.) }\end{array}$ & 2.49 \\
\hline 20 & 31.94 & $\begin{array}{l}\text { Stigmast-7-en-3-ol, (3. } \\
\text { beta., 5. alpha., 24S) }\end{array}$ & 0.25 \\
\hline
\end{tabular}

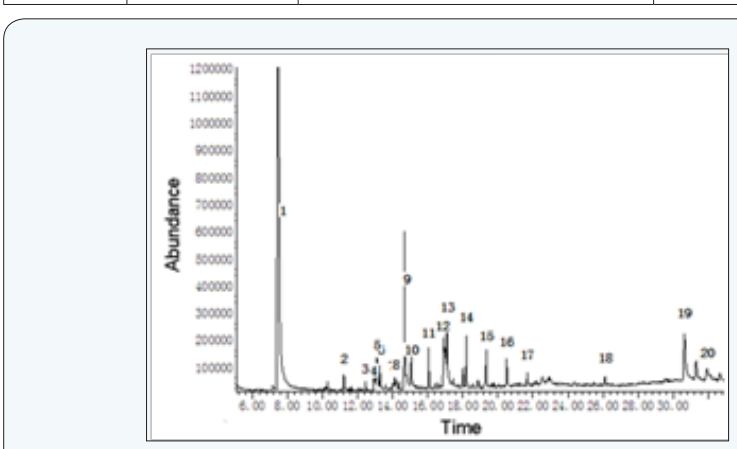

Figure S1: GC-MS analysis of XSC from the husks of XS. 


\section{Structure elucidation of DMP}

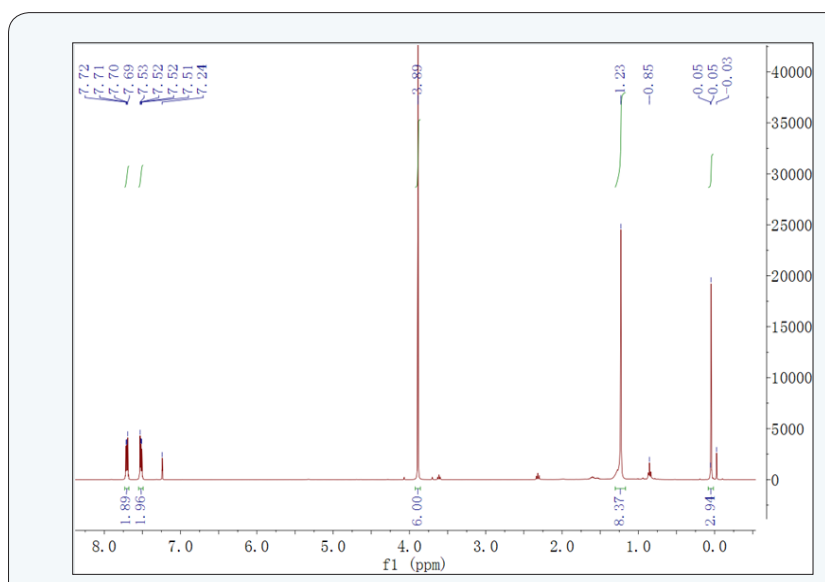

Figure S2: ${ }^{1} \mathrm{H}-\mathrm{NMR}$ of DMP.

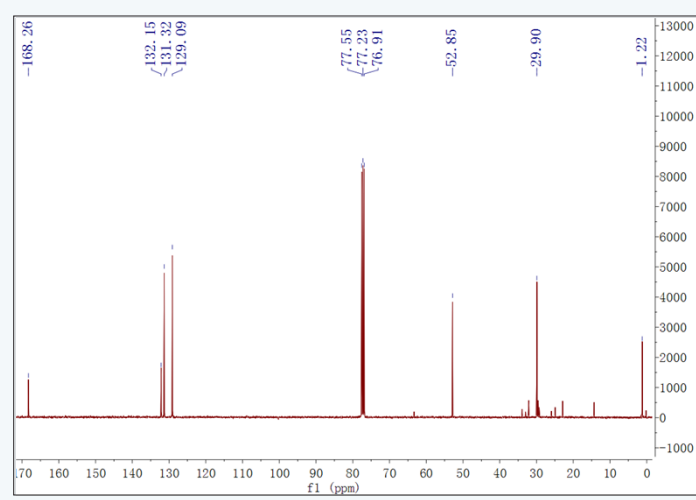

Figure S3: ${ }^{13} \mathrm{C}-\mathrm{NMR}$ of DMP.

DMP, colorless gum. ${ }^{1} \mathrm{H}-\mathrm{NMR} \quad\left(\mathrm{CDCl}_{3}, 400 \mathrm{MHz}\right)$ (Supplementary Figure S2), $\delta: 7.72(2 \mathrm{H}, \mathrm{m}, \mathrm{H}-3,6), 7.54(2 \mathrm{H}$, $\mathrm{m}, \mathrm{H}-4,5), 3.91$ (6H, s, OMe $\times 2) ;{ }^{13} \mathrm{C}-\mathrm{NMR}\left(\mathrm{CDCl}_{3}, 100 \mathrm{MHz}\right)$ (Supplementary Figure S3) $\delta: 167.10$ (C-7,8), 131.00 (C-1,2), $130.10(\mathrm{C}-3,6), 127.90$ (C-4,5), 51.70 (OMex2). This compound was identified as DMP [15]. To the best of our knowledge, DMP was isolated from the genus Xanthoceras for the first time.

\section{In vitro antitumor activity}

Considering the fact that MTT method is still one of the most widely used assays for testing cytotoxic effects of components and that consists of a simple, sensitive, fast, and cheap assay [12], the antitumor activities of DMP, XSC, and PTX (paclitaxel) at different concentrations against A549, HepG2, MGC-803, and MFC cell lines were examined by the MTT assay, and the results were shown in (Figure 1\&2) and Supplementary (Figure S4 \& S5) respectively. In particular, PTX (the positive control) exhibited significant inhibition ratio in a concentration-dependent manner, and the IC50 values against A549, HepG2, and MGC-803 cell lines were $31.31 \mu \mathrm{g} / \mathrm{mL}, 7.17 \mu \mathrm{g} / \mathrm{mL}, 0.97 \mu \mathrm{g} / \mathrm{mL}$, respectively, while the $\mathrm{IC}_{50}$ value against MFC cell line was more than $50 \mu \mathrm{g} /$ mL. Furthermore, it was found that both XSC and DMP exhibited antitumor activities against the growth of A549, HepG2, MGC803, and MFC cell lines in vitro under the conditions described in this research, compared with the blank control. At the highest concentration $(500.00 \mu \mathrm{g} / \mathrm{mL})$, the inhibition rates of XSC against A549, HepG2, MGC-803, and MFC cell lines were 85.50\%, $68.13 \%, 77.23 \%$, and $71.56 \%$, respectively; and the inhibition rates of DMP against A549, HepG2, MGC-803, and MFC cell lines were $85.57 \%, 79.07 \%, 82.60 \%$, and $78.75 \%$, respectively. In particular, XSC exhibited significantly higher antitumor activities against A549, HepG2, MGC-803, and MFC cell lines in vitro (Figure 1), but no $\mathrm{IC}_{50}$ values were obtained. As shown in (Figure 1), the inhibitory effect of XSC against A549, HepG2, MGC-803, and MFC cells appeared to be concentration-dependent, with the range of $500.00 \mu \mathrm{g} / \mathrm{mL}$ to $15.63 \mu \mathrm{g} / \mathrm{mL}$. When compared to XSC, DMP exhibited poor activities against the growth of A549, HepG2, MGC-803 cell lines, yielding IC $_{50}$ values of $166.80 \pm 1.21 \mu \mathrm{g} / \mathrm{mL}$, $222.20 \pm 1.47 \mu \mathrm{g} / \mathrm{mL}, 188.90 \pm 1.29 \mu \mathrm{g} / \mathrm{mL}$, respectively, where no IC50 value was obtained for MFC cell line. Furthermore, as shown in (Figure 1), the inhibitory effect of DMP against A549, HepG2, MGC-803, and MFC cells also appeared to be concentrationdependent, with the range of $500.00 \mu \mathrm{g} / \mathrm{mL}$ to $15.63 \mu \mathrm{g} / \mathrm{mL}$. However, with decreasing concentrations, the concentrationdependent effect disappeared. So, we could conclude that XSC and DMP had antitumor effect in vitro. Furthermore, DMP might be responsible for part of the in vitro antitumor activity of XSC. However, As in section 2.3, we concluded that we should not ignore the possibility that other minor compounds in XSC might also function as antitumor agents or that the antitumor activity might be the result of a combined or synergistic effects of some undetected compounds in XSC in this study.

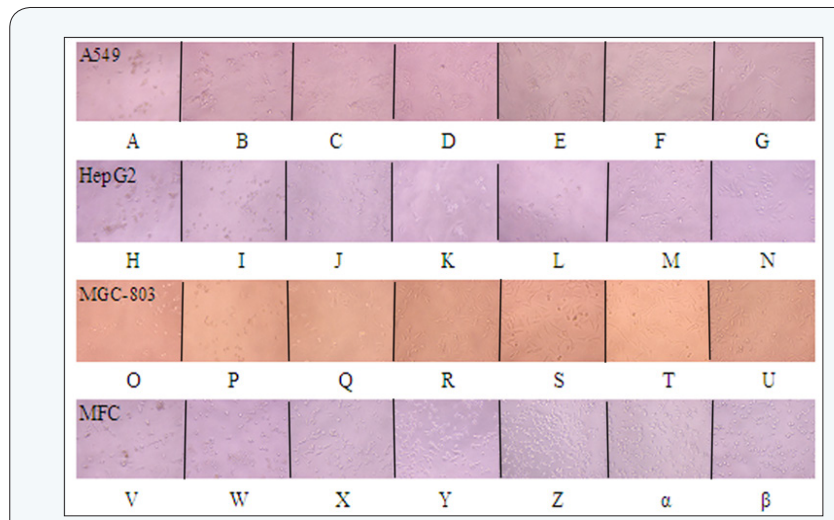

Figure S4: Images (20xmagnification) for changes observed in cell morphology after treatment with DMP (from $500.00 \mu \mathrm{g} / \mathrm{mL}$ to $15.63 \mu \mathrm{g} / \mathrm{mL}$ ) and blank control against A549 (A, B, C, D, E, F, G), HepG2 (H, I, J, K, L, M, N), MGC-803 (O, P, Q, R, S, T, U), and MFC $(\mathrm{V}, \mathrm{W}, \mathrm{X}, \mathrm{Y}, \mathrm{Z}, \alpha, \beta)$ cell lines.

Morphological changes of A549, HepG2, MGC-803, and MFC cell lines against blank control and treated groups of XSC, DMP, paclitaxel (PTX) were observed under an inverted microscope (Figure 2 \& Supplementary Figure S4 \& S5). A549, HepG2, MGC803, and MFC cell lines in the blank control group were intact (i.e., no cell damage), while A549, HepG2, MGC-803, and MFC cells treated with PTX (positive control group), XSC, and DMP presented with classic morphological features of apoptosis (i.e., chromatin condensation, nucleic fragmentation, and 


\section{Journal of Complementary Medicine \& Alternative Healthcare}

apoptotic body formation). Furthermore, the concentrationresponse effects of XSC and DMP at various concentrations (Supplementary Figure S4 \& S5) was also observed, which was in accordance with the results in (Figure 1). Low concentration treatment of both XSC and DMP showed no apoptosis or necrosis cells; however, when cells were exposed to high concentrations of PTX, DMP, and XSC, the cell numbers decreased dramatically and the morphology shrank significantly. Our data supported this publication [16] that high concentration of antioxidants might possess pro-oxidant effects, and cause cancer cells apoptosis, but the underlining mechanisms needed to be revealed.

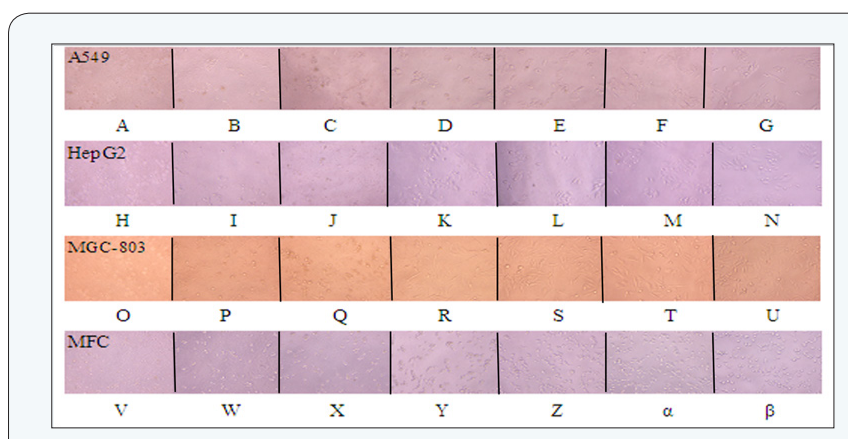

Figure S5: Images (20×magnification) for changes observed in cell morphology after treatment with XSC (from $500.00 \mu \mathrm{g} / \mathrm{mL}$ to $15.63 \mu \mathrm{g} / \mathrm{mL}$ ) and blank control against A549 (A, B, C, D, E, F, G), HepG2 (H, I, J, K, L, M, N), MGC-803 (O, P, Q, R, S, T, U), and $M F C(V, W, X, Y, Z, \alpha, \beta)$ cell lines.

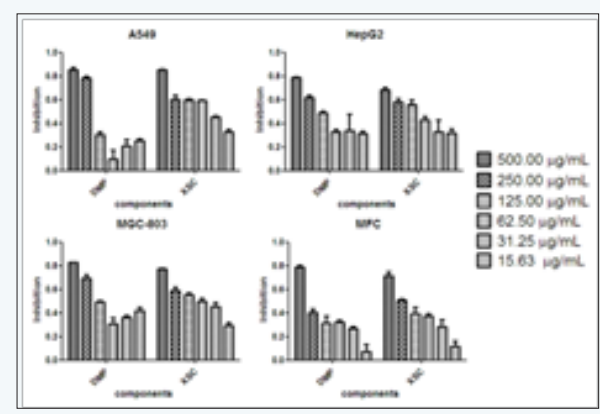

Figure 1: Effects of DMP and XSC on the proliferations of A549, HepG2, MGC-803, and MFC cell lines (data are the mean \pm SD. for three replicates).

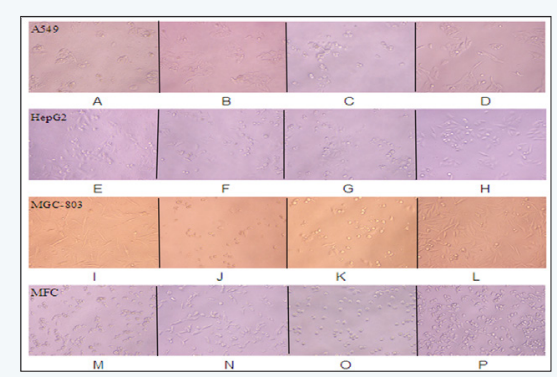

Figure 2: Representative images (20×magnification) for changes observed in cell morphology after treatment with XSC $(62.50 \mu \mathrm{g} /$ $\mathrm{mL})$, DMP $(125.00 \mu \mathrm{g} / \mathrm{mL})$, and PTX $(50.00 \mu \mathrm{g} / \mathrm{mL})$ against A549 (A, B, C, D), HepG2 (E, F, G, H), MGC-803 (I, J, K, L), and MFC $(\mathrm{M}, \mathrm{N}, \mathrm{O}, \mathrm{P})$ cell lines. DMP, dimethyl phthalate $(\mathrm{A}, \mathrm{E}, \mathrm{I}, \mathrm{M})$; XSC, the chloroform fraction (B, F, J, N); PTX, Paclitaxel (C, G, K, O); UTC, untreated control (D, H, L, P).

\section{Antioxidant activity}

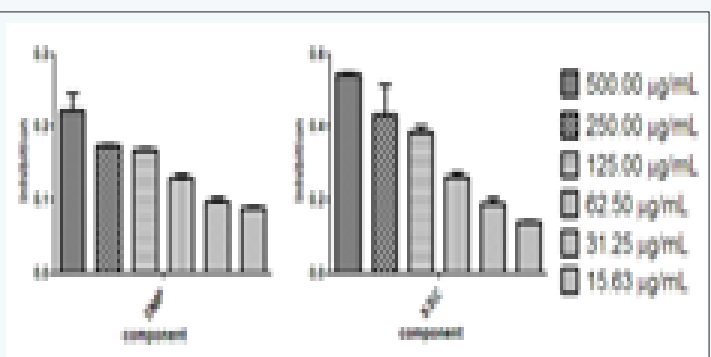

Figure 3: The radical-scavenging activity of XSC and DMP isolated from the husks of XS. ABTS solution was provided daily and diluted to an absorbance of $0.70 \pm 0.02$ at $734 \mathrm{~nm}$. After DMP and XSC (500.00, 250.00, 125.00, 62.50, 31.25, 15.63 $\mu \mathrm{g} / \mathrm{mL}$ ) reacted with the ABTS radical solution for $10 \mathrm{~min}$, the absorbance value (Ai) of ABTS at $734 \mathrm{~nm}$ was tested, and the percentage inhibitions were calculated.

Free radicals and reactive oxygen species are associated with several physiological and pathological processes, such as cancer and inflammation [17]. The ABTS method has been a popular radical scavenging assay for natural components [18], which was applied in in the present study to check the antioxidant activity of DMP and XSC. L-ascorbic acid was used as positive control, with $\mathrm{SC}_{50}$ value of $43.56 \pm 1.09 \mu \mathrm{M}$ against ABTS radical. As shown in (Figure 3), at the highest concentration (500.00 $\mu \mathrm{g} / \mathrm{mL}$ ), the inhibition rate of XSC against ABTS was $54.47 \%$; and the inhibition rate of DMP against ABTS was $22.30 \%$. In particular, XSC exhibited significantly higher antioxidant activity against ABTS, with $\mathrm{SC}_{50}$ value $120.40 \pm 1.36 \mu \mathrm{g} / \mathrm{mL}$. As shown in (Figure 3), the inhibitory effect of XSC against ABTS appeared to be concentration-dependent, with the range of $500.00 \mu \mathrm{g} / \mathrm{mL}$ to $15.63 \mu \mathrm{g} / \mathrm{mL}$. When compared to XSC, DMP exhibited poor activity against ABTS assay, where no $\mathrm{IC}_{50}$ value was obtained. But as shown in (Figure 3), the inhibitory effect of DMP against ABTS free radical also appeared to be concentration-dependent, with the range of $500.00 \mu \mathrm{g} / \mathrm{mL}$ to $15.63 \mu \mathrm{g} / \mathrm{mL}$. So, we could conclude that XSC and DMP possessed antioxidant activity in vitro. Furthermore, DMP might be responsible for part of the in vitro antioxidant activity of XSC. Likewise, as far as the antioxidant activity of XSC was concerned, we should not ignore the possibility that other trace compounds in XSC might also act as antioxidant agent or that the antioxidant activity might be the result of a concerted or associated effects of some undetected compounds in XSC in this study.

\section{The relationships between the antitumor and antioxidant activities}

As can be seen from (Table 2), the correlation coefficients $\left(\mathrm{R}^{2}\right)$ between antioxidant and antitumor capacities at different concentrations of XSC and DMP varied from 0.82 to 0.99 , and very good correlations were found between the antioxidant and anticancer capacities of XSC and DMP. According to the calculations of the experimental data, it was implied that scavenging free 


\section{Journal of Complementary Medicine \& Alternative Healthcare}

radicals might be one of the mechanisms of the tumor-inhibiting activities of XSC and DMP, which was in accordance with the literature report that free radicals could cause cell mutations in human body and the mutations might generate abnormality cell hyperplasia, namely tumor cell. It was worth noting that DMP was found to have other biological activities according to literature report. Besides its use as plasticizer, DMP was also used in the insecticides, insect repellants, cosmetics, perfumes, agriculture plastics, and agricultural detergents $[19,20]$.

Table 2: Correlation coefficients $\left(R^{2}\right)$ between antioxidant and antitumor capacities of XSC and DMP at different concentrations.

\begin{tabular}{|c|c|c|c|c|c|}
\hline \multicolumn{2}{|c|}{} & A549 & HepG2 & MGC-803 & MFC \\
\hline \multirow{2}{*}{ ABTS } & DMP & 0.82 & 0.95 & 0.87 & 0.90 \\
\cline { 2 - 6 } & XSC & 0.93 & 0.99 & 0.96 & 0.96 \\
\hline
\end{tabular}

\section{Conclusion}

In conclusion, both GC-MS analysis and phytochemistry investigation showed that DMP was the major constituent of XSC, which was the first study of the lipophilic composition from the husks of XS. Furthermore, we found that XSC and DMP could concentration-dependently inhibit the growth of A549, HepG2, MGC-803, and MFC cell lines proved by two indexes including percentage inhibitions and morphological changes, and could also scavenge ABTS free radicals. Moreover, we suggested that, in XSC, the antioxidant and antitumor activities could be partly attributable to DMP. In addition, on the basis of the calculations of the experimental data and the literature investigations, it was implied that scavenging free radicals might be one of the mechanisms of the tumor-inhibiting effects of XSC and DMP.

\section{Acknowledgements}

The study was financially supported by the National Nature Science Foundation of China (Nos. 21405164 and 21575150), the scientific research project of Central Asia Drug Discovery and Development Centre of Chinese Academy of Sciences (No. CAM201404), CAS Pioneer Hundred Talents Program, and Postdoctoral Research Projects in Gansu Province.

\section{References}

1. Guo HH, Li QQ Wang TT, Hu Q, Deng WH, et al. (2014) XsFAD2 gene encodes the enzyme responsible for the high linoleic acid content in oil accumulated in Xanthoceras sorbifolia seeds. J Sci Food Agr 94(3): 482-488.

2. Fu YJ, Zu YG, Wang LL, Zhang NJ, Liu W, et al. (2008) Determination of fatty acid methyl esters in biodiesel produced from yellow horn oil by LC. Chromatographia 67(1): 9-14.

3. Yu LL, Tang XL, Chen LX, Wang MM, Jian JF, et al. (2012) Oleanane-type triterpenoid saponins from Xanthoceras sorbifolia Bunge. Fitoterapia 83(8): 1636-1642.
4. Yu LL, Wang XB, Wei XC, Wang MM, Chen LX, et al. (2012) Triterpenoid saponins from Xanthoceras sorbifolia Bunge and their inhibitory activity on human cancer cell lines. Bioorg Med Chem Lett 22(16): 5232-5238.

5. Guo Y, Wang SC, Dou DQ (2009) Determination of the content of total saponins in the husks of Xanthoceras Sorbifolia Bunge. Journal of Liaoning University of TCM 11: 165-166.

6. Li ZL, Li X, Li LH, Li N, Yu M, et al. (2005) Two new triterpenes from the husks of Xanthoceras sorbifolia. Planta Med 71(11): 1068-1070.

7. Li ZL, Li DY, Li X, Li N, Meng DL (2006) A new alkaloid from the husk of Xanthoceras sorbifolia. Yao Xue Xue Bao 41(12): 1197-1200.

8. Zhang DH, Wu HX, Xia ZM, Wang C, Cai JB, et al. (2012) Partial characterization, antioxidant and antitumor activities of three sulfated polysaccharides purified from Bullacta exarata. J Funct Foods 4(4): 784-792.

9. Murugan K, Iyer VV (2014) Antioxidant and antiproliferative activities of extracts of selected red and brown seaweeds from the Mandapam Coast of Tamil Nadu. J Food Biochem 38(1): 92-101.

10. Haendeler J, Hoffmann J, Zeiher AM, Dimmeler S, (2004) Antioxidant effects of statins via S-nitrosylation and activation of thioredoxin in endothelial cells - a novel vasculoprotective function of statins. Circulation 110(7): 856-861.

11. Nunes GBL, Policarpo PR, Costa LM, Da Silva, TG, Militao, et al. (2014) In vitro antioxidant and cytotoxic activity of some synthetic riparinderived compounds. Molecules 19(4): 4595-4607.

12. Frozza COD, Garcia CSC, Gambato G, de Souza MDO, Salvador M, et al (2013) Chemical characterization, antioxidant and cytotoxic activities of Brazilian red propolis. Food Chem Toxicol 52: 137-142.

13. Yang CY, Liu ZQ Zou K, Wang JZ, Zhou, et al. (2009) Preliminary experimental study on the anti-tumor effect of Tupistra chinensis Bak. in vitro. Lishizhen Medicine and Materia Medica Research 20: 23902392.

14. Yang CY, Yang Y, Aisa HA, Xin XL, Ma HR, et al. (2012) Bioassay-guided isolation of antioxidants from Astragalus altaicus by combination of chromatographic techniques. J Sep Sci 35(8): 977-983.

15. Geng JL, Geng CA, Chen JJ (2012) Chemical constituents of Swertia cincta. Nat Prod Res Dev 24(1): 42-46.

16. Jiang FS, Li WP, Huang YF, Chen YT, Jin B, et al. (2013) Antioxidant, antityrosinase and antitumor activity comparison: The potential utilization of fibrous root part of Bletilla striata (Thunb.) Reichb.f. Plos One 8(2): e58004.

17. Nunes GBL, Policarpo PR, Costa LM, Da Silva, TG, Militao, et al. (2014) In vitro antioxidant and cytotoxic activity of some synthetic riparinderived compounds. Molecules 19(4): 4595-4607.

18. Huang GJ, Wang BS, Lin WC, Huang SS, Lee CY, et al. (2012) Antioxidant and anti-inflammatory properties of Longan (Dimocarpus longan Lour.). Evid Based Complement Alternat Med 2012: 709483.

19. Pranaw K, Singh S, Dutta D, Chaudhury S, Ganguly S, et al. (2014) Biodegradation of dimethyl phthalate by an entomopathogenic nematode symbiont Xenorhabdus indica strain KB-3. Int Biodeter Biodegr 89: 23-28.

20. Li ZL, Li X, Li N, Li W, Sha Y (2005) Studies on the chemical constituents of the husks of Xanthoceras sorbifolia Bunge. Journal of Shenyang Pharmaceutical University 22(4): 271-272. 
Your next submission with JuniperPublishers will reach you the below assets

- Quality Editorial service

- Swift Peer Review

- Reprints availability

- E-prints Service

- Manuscript Podcast for convenient understanding

- Global attainment for your research

- Manuscript accessibility in different formats (Pdf, E-pub, Full Text, audio)

- Unceasing customer service

Track the below URL for one-step submission https://juniperpublishers.com/online-submission.php 